\title{
The Out-of-Plane Bending Behavior of Brick Infill Walls Strengthened with Perforated Steel Plates
}

\author{
Comportamiento a flexión fuera del plano de muros de relleno de mampostería \\ reforzados con placa de acero perforada
}

\author{
Bengi Aykac \\ Gazi University, Ankara, Turkey \\ Department of Civil Engineering \\ E-mail:baykac@gazi.edu.tr \\ Sabahattin Aykac \\ Gazi University, Ankara, Turkey \\ Department of Civil Engineering \\ E-mail:saykac@gazi.edu.tr
}

\author{
Ilker Kalkan \\ Kirikkale University, Kirikkale, Turkey \\ Department of Civil Engineering \\ E-mail:ilkerkalkan@kku.edu.tr \\ Meryem Bocek \\ Gazi University, Ankara, Turkey \\ Department of Civil Engineering \\ E-mail:meryembocek@gazi.edu.tr
}

Information on the article: received: January 2015, reevaluated: December 2015, accepted: May 2016

\begin{abstract}
The brick infill walls cease to contribute to the lateral strength and stiffness of a structure as soon as they fail in a brittle manner in the early stages of an earthquake. Recent studies indicated that the perforated steel plates externally bonded to both faces of a wall lead to two benefits. First, the increase in the lateral strengths and rigidities of the walls increase the overall lateral strength and stiffness of the structure. Secondly, the increase in the ductilities of the walls allows the walls to absorb higher amounts of the earthquake-induced energy before failure so that smaller amounts of energy are required to be absorbed by the bearing structural members. The present study is dedicated to investigate the efficiency of this technique on the behavior of brick walls under out-of-plane bending moments, induced by the blast effect of an explosion or pressure from the soil, wind or snow next to the wall. A brick wall strengthened with perforated steel plates and a brick wall strengthened with perforated steel plates and steel strips on both faces were subjected to four-point bending. The steel plates greatly contributed to the bending capacities of the walls. The use of steel strips on the plates did not affect the flexural capacity of the wall, while increasing the ductility of the wall considerably.
\end{abstract}

\section{Keywords:}

- out-of-plane bending

- perforated steel plate

- brick wall

- infill wall

- seismic behavior 


\section{Resumen}

Los muros de relleno de mampostería dejan de contribuir a la rigidez y resistencia lateral de una estructura en cuanto fallan de manera frágil durante las primeras etapas de un sismo. Estudios recientes indican que placas de acero perforadas adheridas externamente a las dos caras del muro conducen a dos beneficios. El primero, el incremento de la resistencia y rigidez lateral del muro que incrementa la resistencia y rigidez lateral global de la estructura. El segundo, el incremento en la ductilidad en el muro que permite que estos absorban mayores cantidades de energía inducida por un sismo antes de su falla, de modo que se requieran cantidades más pequeñas de energía para absorberse por los miembros estructurales de soporte. El presente estudio se dedica a investigar la eficacia de esta técnica de refuerzo en el comportamiento de muros de mampostería sujeta a flexión fuera del plano, inducida por el efecto de una explosión, presión del suelo, nieve o viento en el muro. Muros de mampostería reforzados con placas de acero perforadas con y sin bandas de acero en ambas caras se sometieron a flexión en cuatro puntos. Las placas de acero contribuyeron en gran medida a la capacidad de flexión del muro. El uso de las bandas de acero en las placas no afectó a la capacidad de flexión del muro, aunque sí aumentó la ductilidad del muro considerablemente.

\section{Descriptores:}

- flexión fuera del plano

- placas de acero perforadas

- muro de relleno

- comportamiento sísmico

\section{Introduction}

The contribution of masonry infill walls to the vertical load-bearing capacity and lateral strength and stiffness of a structure is generally ignored and these members are considered as non-bearing elements of a structure. Among various seismic retrofitting techniques of buildings, strengthening the infill walls and integrating them to the structural system has been extensively investigated in the last decades.

The infill wall strengthening applications aim at not only increasing the overall lateral strength and stiffness of the structure by increasing the limited contribution of infill walls but also providing the infill walls with considerable ductility and energy absorption capacity so that the free earthquake-induced energy can be absorbed by these non-bearing elements instead of the structural system. Integration of the infill walls to the frame also prevents the collapse of the infill walls, which is one of the major causes of danger to the inhabitants during an earthquake.

Aykac and his companions (Aykac et al., 2014; Aykac et al., 2013; Kalkan et al., 2013) conducted an extensive research program on an innovative strengthening technique for masonry infill walls. In this technique, perforated steel plates are bonded to both faces of the wall and connected to each other and the wall with the help of post-tensioned bolts. In addition to the ductile stress-strain properties, recyclable, fireresistant and non-cancerogenic nature of steel and the economy of the procedure, this method was adopted due to its following advantages:
1. The high deformation capacities of the plates thanks to the elongations of the perforations contribute to the ductilities of the strengthened walls.

2. The presence of plate perforations facilitate drilling of the bolt holes into the wall.

3. Epoxy, which has several drawbacks including the high cost and low fire resistance, is not needed in this technique.

4. The strengthening plates can be covered with plaster for appearance.

5. Holes can be drilled without damaging the water and power fixtures in the wall if the locations of the fixtures are marked on the wall. These marks are visible thanks to the perforations of the plates.

The monotonic diagonal and reversed cyclic lateral loading tests on infill walls and reversed cyclic lateral loading tests on infilled frame specimens indicated that this technique increases the ductilities, lateral strength and stiffness values and energy absorption capacities of the infill walls and the infilled frames to a major extent.

The lateral earthquake forces on the structure induce diagonal compression forces to the infill walls. The present technique proved to effectively improve the wall behavior when the wall is subjected to diagonal forces. Nevertheless, masonry infill walls might be subjected to loading effects other than the vertical and diagonal compression forces in their service lives. The blast effect of an explosion, the pressure applied by the soil or snow-avalanche in rural habitations, ground shaking transverse to the plane of the wall, etc. may re- 
sult in an infill walls to be subjected to out-of-plane loading. The behavior of infill walls under out-of-plane loading and the influence of different strengthening techniques on this behavior has been subject to several studies in the literature. Ayman (2007) tested unreinforced masonry red brick walls strengthened with

E-glass/epoxy and carbon/epoxy composite systems with different fiber orientations under out-of-plane bending and showed the efficiency of this technique on improving the out-of-plane flexural behavior of unreinforced walls. Razaqpur et al. (2007) established that reinforced concrete panels strengthened with GFRP (Glass Fiber Reinforced Polymer) laminates remain intact when subjected to blast loading unlike plain reinforced concrete panels. Crawford et al. (2008) described the advantages of different strengthening techniques, including the use of polymers, shotcrete, sheet metal, in improving the blast resistance of masonry walls. Bui et al. (2010) investigated the effects of strengthening the masonry walls with horizontal and vertical CFRP (Carbon Fiber Reinforced Polymer) strips on the out-of-plane bending behavior. The tests indicated that the strips increased the out-of-plane bearing capacity of the walls about $140 \%$. Mierzejewski (2010) investigated the effect of the near-surface mounted (NSM) GFRP and stainless steel bars and externally-bonded GFRP and CFRP strips on the out-of-plane flexural behavior of unreinforced masonry walls. The lateral loads were applied to the top of the wall in such a way that they simulate the lateral earthquake loads acting perpendicular to the strong direction of the wall. The NSM steel bars and externally-bonded FRP strips effectively improved the out-of-plane bending behavior of the walls while the NSM GFRP bars, separating from the wall with the epoxy grout surrounding the bars, did not yield to significant improvement in the wall behavior. Dizhur et al. (2014) conducted tests on full-scale unreinforced masonry walls, which indicated the effectiveness of the near-surface-mounted CFRP strips on improving the strengths and ductilities of these walls under out-ofplane bending.

FEMA 306 (FEMA 1998) defines four different modes of failure for infill walls, namely bed-joint sliding, diagonal cracking (diagonal tension failure), corner compression and out-of-plane failure. The first three of these failure modes pertain to in-plane forces and stresses in an infill wall. The final mode, on the other hand, takes place when an infill wall is subjected to ground shaking transverse to the plane of the wall. The present study is dedicated to the influence of the strengthening method developed by Aykac and his companions (Aykac et al., 2014; Aykac et al., 2013; Kalkan et al., 2013) on the out-of-plane flexural behavior of hollow brick infill walls. FEMA 306 (FEMA 1998) states that out-ofplane failure of infill walls is generally unlikely to take place except the infill walls at high stories of a structure. The uniform pressure $(w)$ that causes out-of-plane failure of an infill wall is obtained from the following formula according to FEMA 306 (FEMA 1998):

$w=\frac{2 \cdot f_{m e}^{\prime}}{(h / t)} \cdot \lambda \cdot R_{1} \cdot R_{2}$

where

$f_{\text {me }}^{\prime} \quad=$ masonry strength

$h$ and $t=$ height and thickness of the wall

$\lambda=$ slenderness parameter

$R_{1} \quad=$ out-of-plane reduction factor

$R_{2} \quad=$ stiffness-reduction factor for bending frame members

EI = flexural rigidity of the weakest frame on the non-continuous side of the infill panel

In the present study, two brick wall specimens, one strengthened with perforated steel plates and the other retrofitted with perforated steel plates and steel strips on both faces, were tested to failure. The specimens were subjected to two-point loading perpendicular to the plane of the wall. The loads were applied at mid-height level of the wall, representing the out-of-plane flexural moments introduced by blast effect or overpressure caused by soil or snow or ground shaking transverse to the plane of the wall. The perforated steel plates were found to have a major contribution to the out-of-plane bending capacity of the wall in such a way that the strengthened walls reached capacities in the order of a reinforced concrete beam of equivalent dimensions and reinforcement. Furthermore, the steel strips were found not to contribute to the bending capacity while increasing the ductility of the wall significantly.

\section{Materials, methods and tests}

In the present study, two strengthened hollow brick infill walls, each with a height of $3000 \mathrm{~mm}$ and a width of $1000 \mathrm{~mm}$, were tested to failure. The specimen S1 was strengthened with perforated steel plates on both faces of the wall. The Specimen S2 was strengthened with perforated steel plates on both faces and three $30 \times 3 \mathrm{~mm}$ steel strips with a clear spacing of $250 \mathrm{~mm}$ on each plate (Figure 1). 


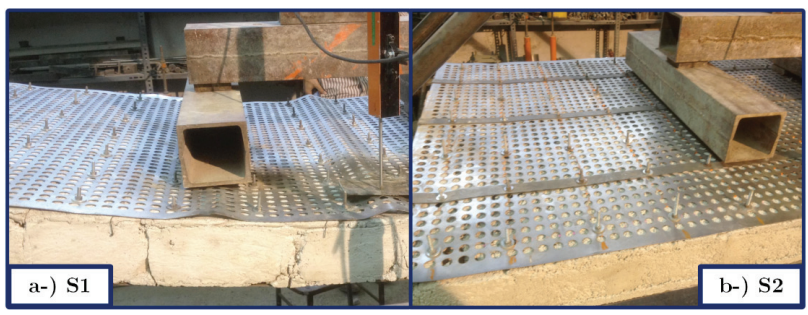

Figure 1. Test specimens

The specimens were composed of 85x190x190 mm hollow bricks, whose horizontal channels were oriented parallel to the width of the wall. The compressive strength values of the bricks parallel to the channels and perpendicular to the channels in the short and long directions were measured as $12.0 \mathrm{MPa}, 2.8 \mathrm{MPa}$ and 3.2 $\mathrm{MPa}$, respectively. The overall thickness of the unstrengthened wall, including the brick and the plaster layers on both faces, was $150 \mathrm{~mm}$. A mortar mixture with a measured compressive strength of $12.3 \mathrm{MPa}$ was used as the binder between the bricks and as the plaster on the faces of the wall. The perforated steel plates had a thickness of $1 \mathrm{~mm}$. Each plate perforation had a diameter of $16 \mathrm{~mm}$ and a clear spacing of $8 \mathrm{~mm}$ from the neighboring perforations along the length and width of the plate. The steel plates and strips had a measured yield strength of 280 $\mathrm{MPa}$. The plates and strips were connected to the wall to each other with the help of M6 anchor bolts, which were post-tensioned with a torque of 3 N.m. This torque value was chosen in a way that the largest post-tensioning forces possible ( $50 \%$ of the axial bolt capacity) could be applied to the wall without causing the failure of the bolts due to the additional stresses in the bolts induced by the out-of-plane bending moments. The bolts were spaced at $150 \mathrm{~mm}$ on center along both the width and height of the wall.

The walls were subjected to two-point loading (Figure 2), with each line of loading located at a distance of $1000 \mathrm{~mm}$ from the end supports and $300 \mathrm{~mm}$ from midspan. The walls extended $200 \mathrm{~mm}$ beyond the simple supports on each side of the span. The mid-span deflection and applied load were measured by an LVDT and a load cell. The specimens were subjected to monotonic transverse loading with the help of a manual hydraulic jack. The load was not applied in increments. Up to the initiation of yielding of the strengthening plate, a loadcontrolled protocol was adopted, while a deformationcontrolled loading protocol was used beyond yielding of the plate up to failure. A loading rate of approximately $0.2 \mathrm{kN}$ per second and a deformation rate of $0.5 \mathrm{~mm}$ per second were adopted in the load-controlled and deformation-controlled stages of loading, respectively.

\section{Discussion of results}

Figure 3 shows the deflections of the specimens against the main load applied by the hydraulic jack. Unlike a plain masonry wall, which fails in a brittle manner short after the formation of flexural cracks in the tension zone, the perforated steel plates in both of the strengthened walls allowed the walls to exhibit a much more ductile behavior compared to a plain wall. Both of the specimens were able to undergo significant deformations before complete failure (Figure 4). The bottom perforated plates resisted the tensile forces in the wall after the formation of the tension cracks and allowed a compression block to form in the plaster layer. The upper perforated steel plates did not contribute to the bending capacities of the walls since they buckled at early stages of loading under the compressive stresses in the wall (Figure 5). The steel strips on the perforated plate in Specimen S2 could not prevent buckling of the compression plate.

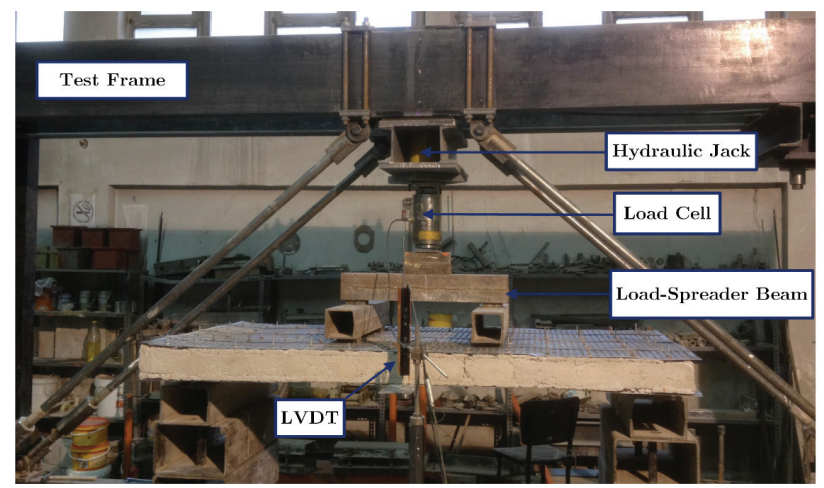

Figure 2. Test setup

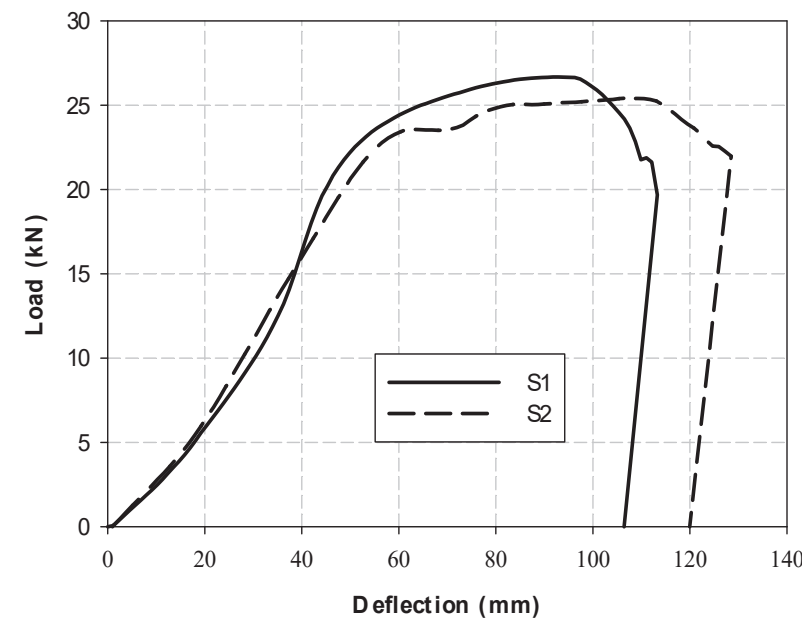

Figure 3. Load-deflection curves of the specimens 


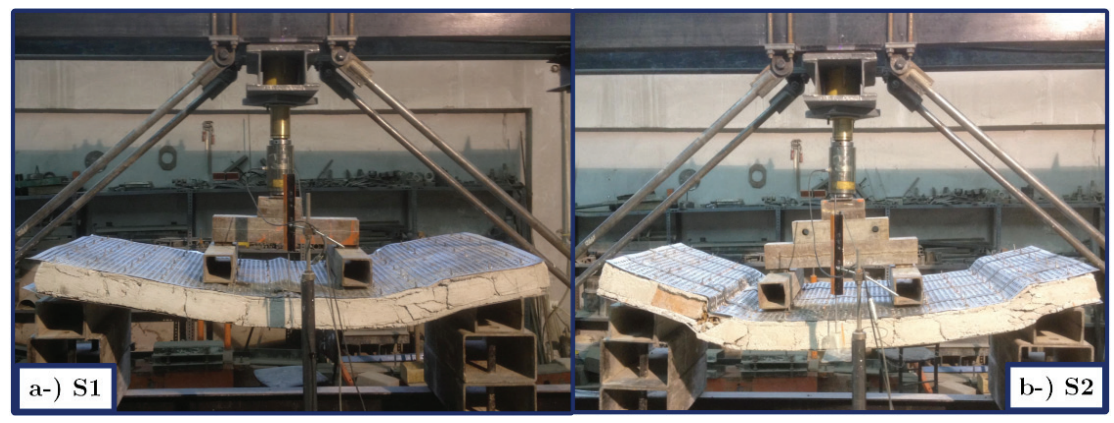

Figure 4. Failure modes of the specimens

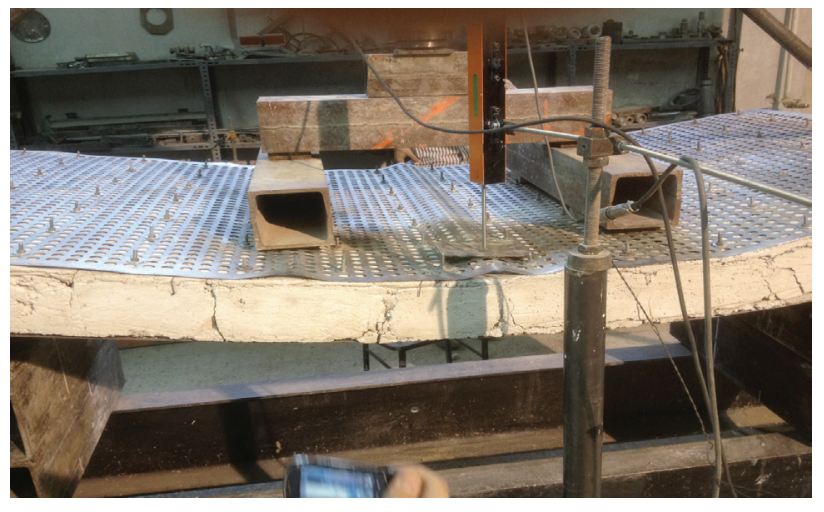

Figure 5. Buckling of the compression plate

Specimen S1 failed at an ultimate bending moment value of $14 \mathrm{kN}$.m, while S2 reached an ultimate bending moment value of $15 \mathrm{kN} . \mathrm{m}$. Accordingly, the use of the steel strips bonded to the perforated steel plates had a very slight contribution to the ultimate bending moment capacity of the strengthened wall. Both of the specimens failed at moments close to the analytical moment value ( $15 \mathrm{kN} . \mathrm{m})$, calculated by taking the moment arm as the full thickness of the plastered wall. The strengthened walls reached approximately the moment capacity of a reinforced concrete beam with identical dimensions and amount of tension reinforcement.

An unstrengthened plain hollow brick wall with dimensions and material properties identical to the respective values of the test specimens has an out-of-plane bending capacity of $1.01 \mathrm{kN}$.m according to Equation (1). In the calculation of this capacity, the values of $R_{1}$ and $R_{2}$ were taken equal to 1.00 and 0.35 based on the values given in FEMA 306 (FEMA 1998). This capacity is smaller than the bending moment created by the selfweight of the wall $(1.83 \mathrm{kN} . \mathrm{m})$, when self-weight acts in transverse direction to the plane of the wall identical to the loading direction in the present tests, implying that the out-of-plane flexural capacity of the wall is not adequate to carry its self-weight. This strengthening tech- nique increased the out-of-plane flexural capacities of the brick walls to 14-15 times the capacity of a plain wall. This increase clearly shows the contribution of the use of perforated steel plates to the out-of-plane bending capacity of a hollow brick infill wall.

Figure 3 indicates that S2 exhibited a more ductile behavior and reached greater deformations before failure compared to S1, implying the contribution of the steel strips to the ductility of a strengthened wall. The ductility factors of S1 and S2 were determined as 2.2 and 2.6, respectively. Ductility factor is the ratio of the deflection at $85 \%$ of the ultimate load beyond the peak to the deflection at the initiation of yielding according to Eurocode 8 (CEN 2003).

\section{Conclusions}

The influence of strengthening with perforated steel plates and steel strips on the out-of-plane bending behavior of hollow brick infill walls was investigated. Two specimens, one strengthened with a perforated plate and the other strengthened with a perforated plate and three additional steel strips on each face, were constructed and subjected to four-point bending. The plates and strips were connected to the wall and to each other with the help of post-tensioned anchor bolts. The loads were applied at the mid-height level of the walls to simulate the flexural moments induced by the blast effect of an explosion or pressure originating from the soil or snow next to the wall. The experiments indicated that the perforated steel plates provide the brick walls with a ductile out-of-plane bending behavior. This strengthening process increased the moment capacity of the brick walls approximately to the capacity of a reinforced concrete beam with identical dimensions and amount of reinforcement and the ductility of the strengthened walls to 2.2-2.6 times the ductility of a plain wall. The use of perforated steel plates increased the out-of-plane bending capacities of hollow brick infill walls to 14-15 times the respective capacity of a plain 
wall, which cannot support even its self-weight when the self-weight acts in transverse direction to the plane of the wall. The use of steel strips on the perforated plates increased the ductility and energy absorption capacity of the strengthened wall, while having a limited contribution to its moment capacity.

A great majority of the studies in the literature on out-of-plane strengthening of infill walls focused on the use of FRP materials in strengthening. Both infill walls and FRP materials have brittle stress-strain properties and limited ductilities. The present study indicated that the use of perforated mild steel plates, whose deformation capacities and ductilities are much greater than FRP materials, not only contributes to the out-of-plane flexural capacity of an infill wall but also increases its ductility and energy absorption capacity. The perforated plates constitute a better alternative for strengthening infill walls since their contribution to the modulus of toughness values of infill walls allows the absorption of earthquake-induced free energy by these non-structural elements to safeguard the bearing elements of a structure during an earthquake.

The conclusions drawn in the present study are based on a limited number of tests. Further experiments are needed to reach more definitive results. The tests on infill walls with different plate thickness, bolt spacing, strip dimensions and strip spacing values will indicate the extents of the contribution of this strengthening technique to the out-of-plane bending capacities and ductilities of infill walls.

\section{References}

Aykac S., Kalkan I., Seydanlioglu M. Strengthening of hollow brick infill walls with perforated steel plates. Earthquakes and Structures, volume 6 (issue 2), February 2014:181-199.

Aykac S., Kalkan I., Aykac B., Seydanlioglu M. Strength and behavior of hollow brick infill walls strengthened with perforated steel plates, in: the $21^{\text {st }}$ Annual International Conference on Composites/ Nano Engineering, Tenerife, Canary Islands, Spain, 2013.

Ayman S.M. Out-of-plane flexural behavior of unreinforced red brick walls strengthened with FRP composites. Composites Part B: Engineering, volume 38 (issues 5-6), July-September 2007: 559-574.

Bui T.T., Limam A., Bertrand D., Ferrier E., Brun M. Masonry walls submitted to out-of-plane loading: experimental and numerical study, in: $8^{\text {th }}$ International Masonry Conference, Dresden, Germany, 2010.

Crawford J., Morrill K., Magallanes J., Wu Y. Retrofit of masonry walls to enhance their blast resistance, in: 2008 Structures Congress, Vancouver, British Columbia, Canada, 2008.

Dizhur D., Griffith M., Ingham J. Out-of-plane strengthening of unreinforced masonry walls using near surface mounted fibre reinforced polymer strips. Engineering Structures, volume 59, February 2014: 330-343.

European Committee for Standardization (CEN). Eurocode 8: design of structures for earthquake resistance-part 1: general Rules, seismic actions and rules for buildings, European Committee for Standardization, 2003.

Federal Emergency Management Agency (FEMA). FEMA 306: Evaluation of earthquake damaged concrete and masonry wall buildings, Federal Emergency Management Agency, 1998.

Kalkan I., Aykac B., Baran M., Babayani R., Aykac S. Delikli çelik levhalarla güçlendirilmiş dolgu duvarların deprem davranışı (in Turkish), in: the Turkish Chamber of Civil Engineers (IMO) Fifth Symposium on Steel Structures, Istanbul Technical University, Istanbul, Turkey, 2013.

Mierzejewski W. Out-of-plane bending of masonry walls with nearsurface-mounted and externally bonded corrosion-resistant reinforcement, MASc (Thesis, Dept. of Civil Engineering), Queen's University, Kingston, Ontario, Canada, 2010.

Razaqpur A.G., Tolba A., Contestabile E. Blast loading response of reinforced concrete panels reinforced with externally bonded GFRP laminates. Composites Part B: Engineering, volume 38 (issues 5-6), July-September 2007:535-546. 


\section{Citation for this article: \\ Chicago style citation}

Aykac, Bengi, Sabahattin Aykac, Ilker Kalkan, Meryem Bocek. The Out-of-Plane Bending Behavior of Brick Infill Walls Strengthened with Perforated Steel Plates. Ingeniería Investigación y Tecnología, XVII, 04 (2016): 429-435.

\section{ISO 690 citation style}

Aykac B., Aykac S., Kalkan I., Bocek M. The Out-of-Plane Bending Behavior of Brick Infill Walls Strengthened with Perforated Steel Plates. Ingeniería Investigación y Tecnología, volume XVII (issue 4), October-December 2016: 429-435.

\section{About the authors}

Bengi Aykac. Is a teaching assistant in the Civil Engineering Department, Gazi University, Ankara, Turkey. She received her B.S., M.S. and Ph.D. from Gazi University, Ankara. Her research interests include behavior of concrete beams strengthened by jacketing techniques, concrete beams strengthened with steel plates, crack repair by epoxy injection.

Sabahattin Aykac. Is an associate professor in the Civil Engineering Department, Gazi University, Ankara. He received his B.S., M.S. and Ph.D. from Gazi University in 1989, 1993, and 2000, respectively. His research interests include strengthening \& repair of concrete beams, earthquake behavior of strengthened concrete beams, concrete beams with openings.

Ilker Kalkan. Is an assistant professor in the Department of Civil Engineering, Kirikkale University, Kirikkale, Turkey. He received his B.S. from the Middle East Technical University, Ankara, Turkey, in 2004; M.S. and Ph.D. from the Georgia Institute of Technology, Atlanta, Georgia, in 2006 and 2009, respectively. His research interests include structural stability, strengthening of concrete beams, steel and concrete beams with transverse openings.

Meryem Bocek. Is a research assistant in the Civil Engineering Department, Gazi University, Ankara, Turkey. She received her B.S. and M.S. from Gazi University, Ankara in 2008 and 2011, respectively. Her research interests include strengthening of concrete and masonry structures. 